\title{
Selected Good Practices in the Hungarian Agricultural Heritage
}

\author{
Csaba Centeri * (D), Dénes Saláta $(\mathbb{D}$, Alfréd Szilágyi, György Orosz, Szilárd Czóbel, Viktor Grónás, Ferenc Gyulai,

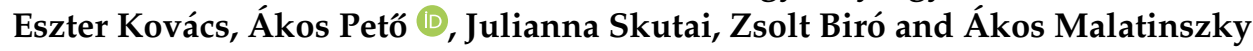

Institute for Wildlife Management and Nature Conservation, Hungarian University of Agriculture and Life Sciences, Páter Károly utca 1, 2103 Gödöllő, Hungary; salata.denes@uni-mate.hu (D.S.); szilagyialfred@gmail.com (A.S.); orosz.gyorgy@uni-mate.hu (G.O.); czobel.szilard@uni-mate.hu (S.C.); gronas.viktor.peter@uni-mate.hu (V.G.); gyulai.ferenc@uni-mate.hu (F.G.); kovacs.eszter@uni-mate.hu (E.K.); peto.akos@uni-mate.hu (Á.P.); skutai.julianna@uni-mate.hu (J.S.); biro.zsolt@uni-mate.hu (Z.B.); malatinszky.akos@uni-mate.hu (Á.M.)

* Correspondence: centeri.csaba@uni-mate.hu

Citation: Centeri, C.; Saláta, D.; Szilágyi, A.; Orosz, G.; Czóbel, S.; Grónás, V.; Gyulai, F.; Kovács, E.; Pető, Á.; Skutai, J.; et al. Selected Good Practices in the Hungarian Agricultural Heritage. Sustainability 2021, 13, 6676. https://doi.org/ $10.3390 /$ su13126676

Academic Editors: Antonio Santoro, Mauro Agnoletti and Imre J. Holb

Received: 7 May 2021

Accepted: 8 June 2021

Published: 11 June 2021

Publisher's Note: MDPI stays neutral with regard to jurisdictional claims in published maps and institutional affiliations.

Copyright: (c) 2021 by the authors. Licensee MDPI, Basel, Switzerland. This article is an open access article distributed under the terms and conditions of the Creative Commons Attribution (CC BY) license (https:/ / creativecommons.org/licenses/by/ $4.0 /)$.
Abstract: Agriculture has always played a determining role in Hungarian landscapes. Forested areas were also under agricultural use; however, their use changed, starting at least from the Middle Ages when the need for new arable fields resulted in a tremendous decrease in forested areas. The protection of forests started for many reasons, saving them for fuelwood and construction materials. This is the reason why there were periods when forests of the Carpathian Basin suffered from considerable pressure, and even today, this pressure continues; however, the source changed from animal husbandry to tourism, forestry, and wildlife management, or rather hunting. This created the need to search for and analyse former sustainable use of the forests. Furthermore, the consideration of the use of trees/treelines is under the scope of helping the climate adaptation of arable fields. Wooded grasslands have also been mapped and various analyses were done, related to their survival. We wish to introduce some of the ancestral forms of the agricultural use of Hungarian farming, where trees play an important role, their origin, distribution, threatening factors, and their future. Sustainable arable farming systems with trees, including wood-pastures; orchard grasslands and conventional, organic, and permaculture horticultural farms with various proportion of tree cover, will be described.

Keywords: sustainable Hungarian farming; agro-heritage; landscape change; land-use change; wooded grassland; orchard grassland; permaculture

\section{Introduction}

The population of the Earth is growing, and feeding this population faces numerous challenges [1-3]. At the same time, the protection of the natural environment, the natural values, the habitats, and the species is also facing challenges at a similar or even larger scale [2]. The answer for increasing food production is normally an intensive farming activity that also induces several problems from environmental protection (erosion, acidification, pollution etc.), through human health to nature conservation (land-use change leads to habitat loss, creating fewer natural habitats or a total change in the natural environment into desert-like arable fields) [4].

There are various emerging patterns to solve the problem of producing more agricultural products with less stress on the environment and more benefit for human health and biodiversity [5]. Some of these practices have roots in the past, in ancient agricultural practices, no matter if they were intentional or accidental. Some of these examples can be found in the form of wooded grasslands and wood-pastures, orchard grasslands, or permaculture with considerable tree cover (partly forested areas).

Wooded grasslands are park-like landscapes, created by long-term human activities (grazing and/or mowing, but we perceive them mainly as pastures in Hungary) and they 
play an important role in the European agricultural heritage [6-8]. More than one third of all European agricultural land areas are covered by grass and their management, yield, and biodiversity are quite diverse. There are intensively managed grasslands with a primary aim of production (mainly fodder), and there are also semi-natural grasslands where the production of goods and conservation of nature is equally possible, providing numerous ecosystem services [9], including the protection of biodiversity [10]. Farmers formed the optimal land character artificially but in concordance with nature during their grazing or mowing [11]. The organization of these wood-pastures (just as well as all grasslands) and their habit have some similarities in the Northern and the Southern Hemisphere [12,13].

The sub-type of wooded grassland is wood-pasture, and from an agricultural and landuse point of view, the park-like wood-pastures belong to the agroforestry systems. They are considered one of the most archaic land-use forms and are under the scope of research $([11,12,14-20]$; furthermore, there is a significant development related to them [21-23]. Agroforestry systems need special management, because natural and semi-natural as well as agriculture-related habitats are also present, so their role in biodiversity protection is of high importance, especially in areas under human intervention [24].

Wooded grasslands are maintained by local communities, so their survival (both as a habitat and as a landscape feature) is not possible without management [25]. Grazing, clearing, and tree management must be done for keeping these agricultural landscapes in a good shape. For this reason, many types of wooded grasslands are threatened. In Hungary, they are the 6th most endangered wooded, semi-natural habitats [26]. They cover approximately 5500 ha-s [27].

Due to the fact that several settlements did not have access to grasslands at all (especially in mountain areas), sylvo-pastoral systems used to have a high importance in Hungary. The forests, consisting mainly of oak and beech, were used for grazing sheep and cattle [28]. These forests were a significant source of fodder. For example, this sylvopastoral system formed the basis of successful sheep breeding in the Börzsöny Mountains (in Hungary) after forest grazing was forbidden [29].

The orchard grassland is also a type of traditional agroforestry, as well as a historical structure of agricultural landscape [30], with not only high historic heritage and biocultural values [31], but also an ecosystem with potentially high resilience towards climate change, which is linked to species and genetic diversity [32]. These orchards host species-rich plant and animal communities, originated by continuous evolution over centuries [33]. Orchard grasslands are a phenomenon authentic to cultural landscapes in temperate Europe, spreading from the Atlantic coast to Central Europe [34]. They are characterised by fruit trees with tall stems, sparsely distributed on either mowed or grazed grassland. The fruit trees are ordinarily of many types and varieties and various ages, some of them over 50 years. The fruit trees serve as a substitute habitat for birds [35] and saproxylic beetles, while species-rich grasslands often grow underneath them [36]. They show a small-scale structure of plot division and evolved during a mutual relationship between man and the landscape. They depend on continuous agricultural activity [37] and remained unaffected by agricultural collectivization. However, they have been marginalized and are no longer a subject of interest from a production perspective.

Management of orchard grasslands has been present in rural Hungary since the Middle Ages. Historic maps show them since the early 19th century. After the 1880's, when the vine-pest (phylloxera) destroyed almost all the vineyards in the hilly areas, several parcels previously used for grape production were re-planted with fruit trees and thus, the coverage of orchard grasslands has grown.

We can consider wood-pastures and orchard grasslands as sustainable farming alternatives to conventional farming as they provide fodder, some fuelwood, fruits, and meat, as well as other materials. Another sustainable alternative to conventional farming is permaculture. Permaculture is a complex management system that goes beyond the principles of organic farming and creates a sustainable human environment $[38,39]$. It is not just a farming system, but a nature-centered approach: based on ethical and management 
principles focused on conserving the Earth and nature. The concept itself was established in the 1970s, in Australia, by Bill Mollison and David Holmgren. After their first publication, permaculture has spread all over the world, but mostly in English-speaking countries [40]. In Hungary, the first trials of permaculture started in the 1990s after a Permaculture Design Course in 1992. Béla Baji has been experimenting for the past 30 years with permaculture practices in his experimental field in Tápiószele [41]. A grass root initiative started in 2006 to promote permaculture in Hungary by enthusiastic practitioners. After 10 years, an official civil organization, Hungarian Permaculture Association (MAPER), has been established (https://permakultura.hu/ (accessed on 31 May 2021)). The organization promotes permaculture via education and research conferences and offers a platform for practitioners, farmers, academics, NGO (Non-Governmental Organization) members, and other stakeholders to cooperate. Today, the association has more than 70 members, involving participants from all stakeholder groups. It also has multiple working groups (education, research, design, etc.) to develop and represent the permaculture movement in Hungary.

One of the best practices or land use that permaculture promotes is forest gardening. This is the most complex form of agroforestry systems, which works with the patterns of the forest ecotype [41]. Multiple layers are established from the high canopy trees, until the annual and perennial plants and soil surface cover. It is still not a well-known practice, although getting more acknowledged internationally [42,43], mostly via the tropical food forests, but there are a few recognized farmers who are trying to establish demonstration farms in the boreal climate [44]. There are some good examples in Hungary too, and interest from farmers and permaculture practitioners is on the rise. Permaculture farming is typical for self-sufficient, small-scale homesteads, but we can find some examples in profitable farms as well, which are producing for selling their product at a market.

The paper aims to present some good agricultural practices from Hungary that have some wooded elements. Two alternatives are presented against the intensive farming system to prove that there is good potential in traditional management systems that are part of our agricultural heritage. They have been worked out for centuries as the cooperation of man and nature, accommodating to the given local geography to provide the expected quantity and quality of food and other materials for the need of humanity. These alternatives can provide goods while protecting natural values and saving the environment from pollution.

To prove the importance of wood-pastures, a mapping method was used. This way it can be seen that their former distribution was quite large. There is still a large number of them are present in the Hungarian landscape. The number of the wood-pastures is already a good indicator of their former frequent use by farmers. The high number of wood-pastures means that there is still a good potential to re-introduce them and enjoy their positive effects on numerous ecosystem services.

Wood-pastures are also known for being environmentally friendly, and their existence is favored by biodiversity. This is also true for orchard grasslands. To prove the positive effects of orchard grasslands on biodiversity, results of botanical surveys are introduced along with listing the protected species.

Based on the literature, it is already known that land abandonment has a negative effect on the different wooded grassland types. Two alternative forms of farm types (organic and permaculture) are described where the mixture of horticultural farms with trees can provide a solution to these problems and assist in the revival of the abandoned wooded grasslands: These types of farms are maintaining this environment- and naturefriendly food production because they either produce food for their family and/or also for the market, so it is the farmers' core interest to maintain the farm and keep it in good condition. To prove some benefits of organic and permaculture farms compared to their conventional/intensive counterparts, soil organic matter measurements were used as an indicator. 


\section{Materials and Methods}

The paper is based on finished and ongoing research. A review of the past and the present situation was carried out for wooded grasslands and orchards grasslands and suggestion for a possible management method for future use were done based on the research. Research showing best practices was chosen to introduce these practices.

\subsection{Study Sites}

\subsubsection{Study Sites for the Description of Wood-Pastures}

The literature review of the wood-pastures covers the whole country (Hungary) with some international outlook. The study site for the description of the wood-pastures is situated in the Northern Medium Mountain Range of Hungary. The mountain range contains several mountains, e.g., Visegrádi (highest point is $699 \mathrm{~m}$ a.s.l.) Börzsöny (highest point is $938 \mathrm{~m}$ a.s.l.), Cserhát (highest point is $727 \mathrm{~m}$ a.s.l.), Mátra (highest point is $1014 \mathrm{~m}$ a.s.l., this is the highest point of Hungary), Bükk (highest point is $960 \mathrm{~m}$ a.s.l.), Zemplén (highest point is $895 \mathrm{~m}$ a.s.l.), just to mention the largest and highest ones. The majority of the mountains are made of volcanic rocks; only the Bükk Mountain is known as "the lime" mountain; however, on the outskirts of the mountain, there are also volcanic and metamorphic rocks. The climate ranges from very cold in the higher areas and on the northern sides of the mountains, while southern sides are much warmer. The amount of precipitation is also heterogeneous, and, as these are among the highest areas of Hungary, the amount of snow is the highest and the duration of the snow cover is the largest. Cold periods are longer and warm periods are shorter than in the lower parts of the country. The heterogeneous climate supports numerous types of vegetation, including forests. The natural vegetation in the highest areas is beech (Fagus sylvatica L.) forests.

\subsubsection{Study Sites for Orchard Grasslands}

The literature review of the orchard grasslands covers the whole country (Hungary) with some international outlook. In Hungary, they are situated in the place of previous forests, mainly turkey oak or oak-hornbeam forests, in lowland and hilly areas (i.e., between approximately $100 \mathrm{~m}$ and $400 \mathrm{~m}$ above sea level) of South-Western Hungary (Vas and Zala county), Southern Transdanubia (Mecsek and Zselic microregions), and the Northern Hungarian Mountain Range (several parts). They occasionally might appear on floodplains as well, such as along the lower section of the Tisza and Maros rivers. Their area is usually inappropriate for cropland management.

\subsubsection{Studied Conventional, Organic, and Permaculture Farms}

Five conventional $(\mathrm{C})$, five organic $(\mathrm{O})$, and five permaculture farms $(\mathrm{P})$ were selected in a semi-circle around Budapest, mainly in an easterly and a north-easterly direction from the capital city, in North-Central Hungary (Figure 1).

Organic —also known/used as biological and/or ecological—farming is an officially and legally acknowledged farm management type that enables the production of healthy food under environmentally friendly and controlled conditions. It seeks to preserve soil and water quality, use renewable resources, and maintain ecological balance (Council Regulation (EC) No 834/2007, https:/ / eur-lex.europa.eu/legal-content/EN/TXT/HTML/?uri= CELEX:32007R0834\&from=hu, IFOAM https:/ / www.ifoam.bio/why-organic/organiclandmarks/definition-organic (accessed on 31 May 2021).

Conventional farming in this paper is defined as a profit-oriented, intensive form of agriculture, which relies primarily on the use of synthetic pesticides and fertilizers and often uses monoculture in large fields.

Permaculture farms were selected from the database of the Hungarian Permaculture Association (https:/ / permakultura.hu/terkep/ (accessed on 31 May 2021). There are 15 farms in the proximity of Budapest; from those we selected five which produce vegetables for the market, as horticulture is the main type in profitable permaculture farms. 
The other farms have either other types of production (animal husbandry, fruit production) or have a focus on self-sufficiency rather than growing for selling.

One of each type was north of Budapest, on Szentendre Island, as this is the main drinking water source of the capital, surrounded by national park areas, so it has a special focus, with high importance from this point of view. All the selected farms were horticultural. A large emphasis was placed on choosing similar, small size farms with $0.3-2$ hectares and with a direct marketing policy (Table 1).

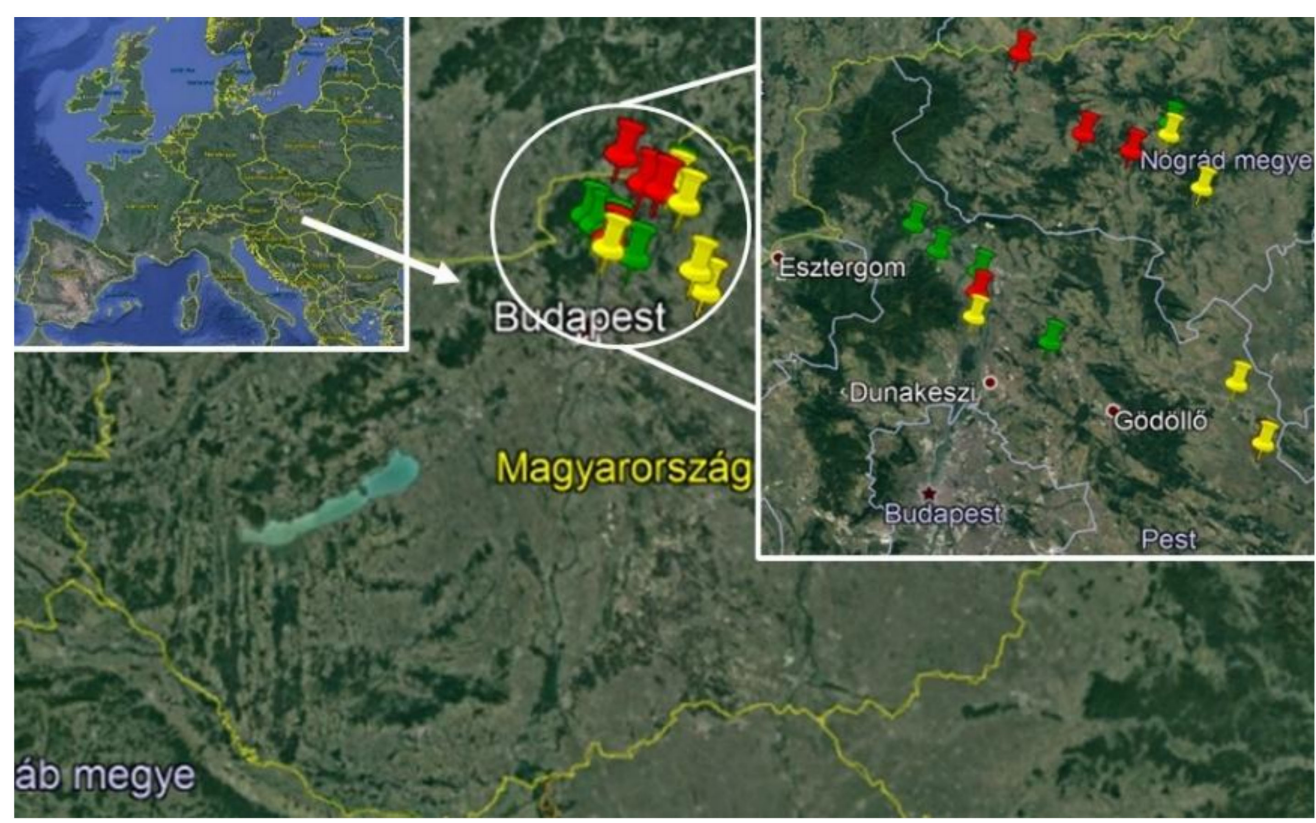

Figure 1. Location of the studied sites (red: conventional, yellow: organic, green: permaculture farms) (Google Earth Pro 2020, own editing).

As for organic farms, the main selection criteria above the production type (horticulture having open fields, not only greenhouses), the scale (small scale, less than 3 hectares), and the location (preferably close to the conventional and permaculture farms) were that they are certified officially by one of the certification bodies. In the case of conventional farms, they applied artificial fertilizers and synthetic plant protection products. We tried to select farms in pairs having similar agro-ecological conditions (soil type and climate). The SOM (Soil Organic Matter) content was selected to be investigated as it is a very good indicator of soil quality and also provides a proxy for certain soil ecosystem services such as carbon sequestration and nutrient cycling. The amount of SOM is related to the management of the different types of farms. Further, the soil has a key importance in sustainable land management, and these alternatives claims their ability to improve soil quality by applying different soil conservation measures (e.g., mulching, adding compost, reducing soil disturbance, etc.).

\subsection{Methodology}

2.2.1. Mapping of Wood-Pastures in the Northern Medium Mountain Ranges of Hungary

Wood-pastures were mapped in the Northern Medium Mountain Ranges of Hungary by Saláta [45]. These mountain ranges have a high forest cover (providing space for the possibility of wood-pastures), as well as a high proportion of national protected areas (including four national parks out of the 10 Hungarian national parks and the largest landscape protection area that creates a higher possibility that wood-pastures will survive). Thus, it is a perfect investigation area to show the history and present state of woodpastures and the changes they suffered during the centuries [45]. The recent map is based on the analyses of the 1:10,000 scale topography maps (available for the whole country, 
created in the 1970s and 1980s) on which the wood-pastures are identifiable, and this was done by Saláta [45] in his doctoral theses. The map was created by the QGIS program, with the raster menu's heatmap renderer module that created a live dynamic heatmap for the point layer of the topographic maps that were used to identify the late 20th-century wood-pastures in the Northern Medium Mountain Ranges of Hungary. The pixel size is $350 \times 350 \mathrm{~m}$; the color is greyscaled.

Field work was also conducted [45] in order to check the recent situation for the presence of these wood-pastures in reality.

Table 1. Soil types and the total thickness of all humus layers (based on their colors) in the studied farms (P = permaculture; $\mathrm{O}=$ organic; $\mathrm{C}=$ conventional).

\begin{tabular}{|c|c|c|c|c|}
\hline Farms & $\begin{array}{l}\text { Size of Horticulture } \\
\text { Production (ha) }\end{array}$ & $\begin{array}{c}\text { Soil Type } \\
\text { (WRB, 2015) }\end{array}$ & $\begin{array}{l}\text { Total Thickness of All } \\
\text { Humus Layers (cm) }\end{array}$ & Comments \\
\hline $\mathrm{C} 1$ & 0.75 & Chernozem & $0-50$ & $\begin{array}{c}\text { conventional tillage, plowing, no mulch, } \\
\text { medium irrigation }\end{array}$ \\
\hline $\mathrm{C} 2$ & 0.5 & Luvisol & 0 & $\begin{array}{l}\text { conventional tillage, plowing, rotation } \\
\text { hoe, no mulch, minimum irrigation, } \\
\text { slightly sandy soil }\end{array}$ \\
\hline C3 & 0.2 & Luvisol & 0 & $\begin{array}{l}\text { no/minimum tillage or shallow } \\
\text { cultivation, professional irrigation } \\
\text { medium irrigation frequent use of }\end{array}$ \\
\hline $\mathrm{C} 4$ & 0.4 & Fluvisol & $0-70$ & $\begin{array}{l}\text { medium irrigation, frequent use of } \\
\text { rotation hoes (soil cultivation+ weed } \\
\text { killing), no mulch }\end{array}$ \\
\hline $\mathrm{C} 5$ & 1.5 & Luvisol & $0-100$ & $\begin{array}{c}\text { intensive irrigation (flooding and } \\
\text { dripping), intensive soil cultivation } \\
\text { (tillage, ridge cultivation, cultivator), } \\
\text { no mulch, }\end{array}$ \\
\hline $\mathrm{O} 1$ & 1 & Chernozem & $0-58$ & $\begin{array}{l}\text { minimal soil disturbance with shallow } \\
\text { cultivation, permanent beds, compost } \\
\text { covering, permanent professional } \\
\text { irrigation, clayey, extensive compost use, } \\
\text { wood chips on cultivation paths, } \\
\text { a yellow, clayey layer at } 60 \mathrm{~cm} \text { depth } \\
\text { continuous irrigation, sandy soil, no }\end{array}$ \\
\hline $\mathrm{O} 2$ & 0.35 & Arenosol & $0-20$ & $\begin{array}{l}\text { mulching, no earthworms probably due } \\
\text { to the very sandy soil texture }\end{array}$ \\
\hline $\mathrm{O} 3$ & 0.3 & Luvisol & $0-41$ & $\begin{array}{l}\text { very clayey soil, medium compaction, } \\
\text { irrigation, permanent beds, shallow } \\
\text { soil cultivation }\end{array}$ \\
\hline $\mathrm{O} 4$ & 0.5 & Luvisol & $0-20$ & $\begin{array}{l}\text { clayey soil, hard compaction, irrigation, } \\
\text { permanent beds, shallow soil cultivation }\end{array}$ \\
\hline O5 & 2 & Luvisol & $0-84$ & $\begin{array}{l}\text { intensive machinery, very weedy, no } \\
\text { mulch, intensive irrigation }\end{array}$ \\
\hline P1 & 0.5 & Arenosol & $0-30$ & $\begin{array}{l}\text { very extensive, no irrigation, lot of } \\
\text { weeds, sandy soil }\end{array}$ \\
\hline P2 & 0.7 & Luvisol & $0-30$ & $\begin{array}{l}\text { minimal soil disturbance with shallow } \\
\text { cultivation, permanent beds, compost } \\
\text { covering, permanent professional } \\
\text { irrigation, clayey, extensive compost use } \\
\text { normal soil cultivation, compost }\end{array}$ \\
\hline P3 & 0.8 & Luvisol & $0-67$ & $\begin{array}{l}\text { covering, permanent } \\
\text { professional irrigation }\end{array}$ \\
\hline $\mathrm{P} 4$ & 0.6 & Luvisol & $0-23$ & $\begin{array}{l}\text { very steep area, rocky/shallow soil, } \\
\text { clayey, soil structure has larger } \\
\text { aggregates }(0.5-1 \mathrm{~cm}) \text {, some irrigation, } \\
\text { some soil tillage }\end{array}$ \\
\hline P5 & 0.2 & Fluvisol & $0-105$ & $\begin{array}{l}\text { minimal irrigation, forest garden, thick } \\
\text { mulch, polyculture beds }\end{array}$ \\
\hline
\end{tabular}




\subsubsection{Botanical Survey of the Selected Orchard Grasslands}

A detailed and frequent (2-3 times per year) botanical survey started in 1998, and the first results were published for various types (orchards, vineyards [30,33]) of abandoned and still managed grasslands. In the recent manuscript, we call attention to the nature conservation values of these orchard grasslands by providing a list of protected plants that were found during the field survey. Plant names refer to the database of Plants of the World online (http:/ / www.plantsoftheworldonline.org/ (accessed on 9 June 2021), while animal names refer to the Fauna Europaea online (https:/ / fauna-eu.org/ (accessed on 9 June 2021).

\subsubsection{Description of Permaculture Farms with Forest Gardens - Case Studies}

Permaculture farms with trees were chosen from the database of the Hungarian Permaculture Association (https: / / permakultura.hu/terkep/ (accessed on 9 June 2021). Four farms are described as case studies.

\subsubsection{Comparative Analysis of Soil Organic Matter in Conventional, Organic, and Permaculture Farms}

The soil was sampled on 11,12, and 13 September 2020, at all farms. Five soil samples from each site were analyzed in the soil laboratory (one physical (Arany-type soil texture coefficient) and 13 chemical ( $\mathrm{SOM}, \mathrm{pH}\left(\mathrm{H}_{2} \mathrm{O}\right)$, total salt, lime $\left(\mathrm{CaCO}_{3} \%\right), \mathrm{N}-\mathrm{NO}_{2}-\mathrm{NO}_{3}$, $\mathrm{Mg}, \mathrm{S}, \mathrm{K}_{2} \mathrm{O}, \mathrm{P}_{2} \mathrm{O}_{5}, \mathrm{Na}, \mathrm{Cu}, \mathrm{Mn}, \mathrm{Zn}$ ) parameters. The laboratory used a Thermo Scientific Evolution 60s UV-Visible spectrophotometer.

The results were recorded in Microsoft Excel software; averages and standard deviations were calculated using Excel. The Shapiro-Wilk test was used for normality analyses of the data. The distribution was normal, so ANOVA was used.

Conventional farms were used as reference farms to compare the performance of the organic and permaculture farms with them.

\section{Results}

\subsection{Wood-Pastures of the Northern Medium Mountain Ranges of Hungary}

The map (Figure 2) shows the 659 wood-pastures identified by Saláta [45]. This map is based on methodology that helps to identify the density of the wood-pastures in the Northern Medium Hungarian Mountain Range.

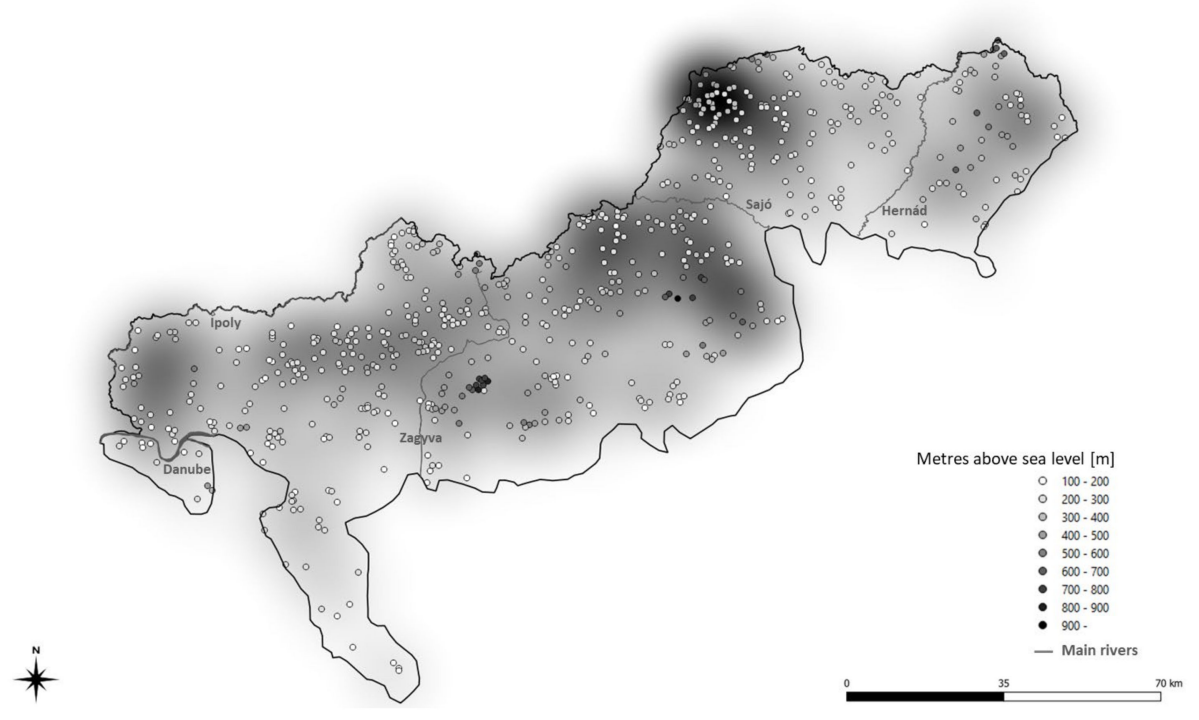

Figure 2. The density of wood-pastures in the Northern Medium Mountain Range of Hungary. Data are based on [45] Saláta (2017); the density map was created by QGIS, and darker shades indicate a greater density of wood-pastures. 
The map shows that the majority of the wood-pastures are related to lowlands; white circles show areas where the elevation is $100-200 \mathrm{~m}$ a.s.1. On the other hand, it is visible that there are spots where the wood-pastures are relatively rare, e.g., the southern part of the mountain range or in other, low lying areas, riverside areas. To show an example of these wood-pastures, a turkey oak-dominated landscape can be seen in Figure 3, nearby the village of Cserépfalu at the foothills of the Bükk Mountain.

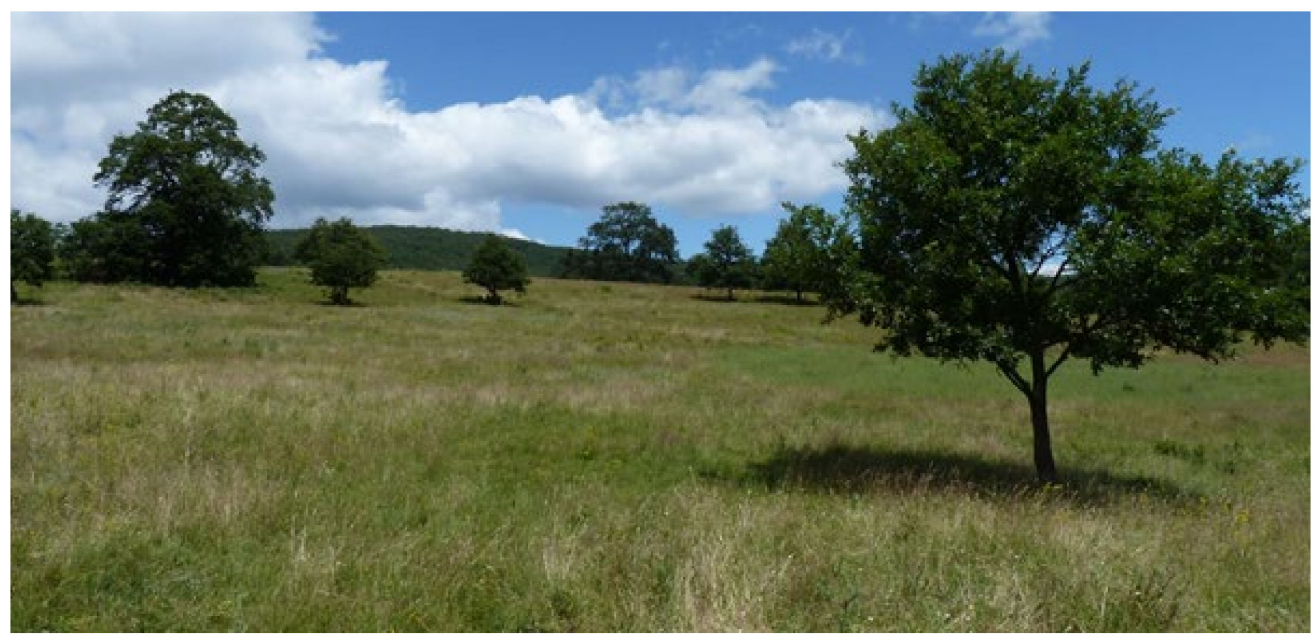

Figure 3. Wood-pasture with uneven-aged turkey oaks near Cserépfalu village (Northern Medium Mountain Range of Hungary) (Photo: D. Saláta 2014).

The figure shows a typical wood-pasture of the studied Northern Mountain Range of Hungary. We can consider this landscape as a type with a medium density of trees. In some of the cases, there are huge areas with only one or two trees, but the opposite can also occur with a much higher density of trees. Another example of a sloping area is from the northeastern corner of Hungary (Figure 4).

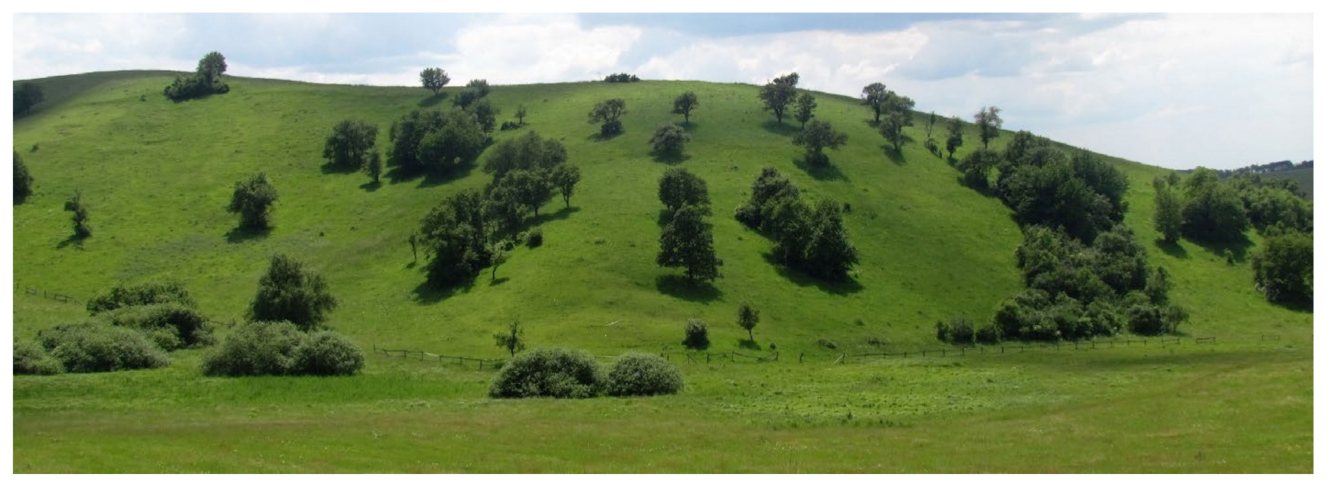

Figure 4. Wood-pasture near Zádorfalva village (Northern Medium Mountain Range of Hungary). (Photo: Á. Malatinszky 2017).

The slopes near Zádorfalva are quite steep, so pasture is one of the viable alternatives to arable farming where severe soil water erosion should occur.

Only 13 of the wood-pastures in the Northern Medium Mountain Range of Hungary are protected by either national or local law:

- $\quad$ http://www.termeszetvedelem.hu/index.php?pg=menu_2774 (accessed on 31 May 2021) — search page of the Ministry of Agriculture for national and local protected areas based on

- $\quad$ the Nature Conservation Law of Hungary (LIII of 1996) and 
- $\quad$ the 13/1997. (V. 28) decree of KTM (Ministry for Environment and Nature) on the registration of protected natural areas and values.

Overall, as of today, there is a total of 200-250 wood-pastures in the Northern Medium Mountain Range of Hungary with various ages and states. Therefore, approximately one-third of the recognizable wood-pastures on the 1970s and 1980s map has disappeared based on the field examination of these wood-pastures [45].

\subsection{Nature Conservation Values of Species Related to Hungarian Orchard Grasslands}

The grassland below the foliage of the fruit trees has been mown regularly (Figure 5). Due to regular mowing usually once a year (during July or August, also to ease the collection of fruits), secondary grasslands generated that are similar to those of foreststeppes or hay meadows, providing a home for nature-protected plant species.

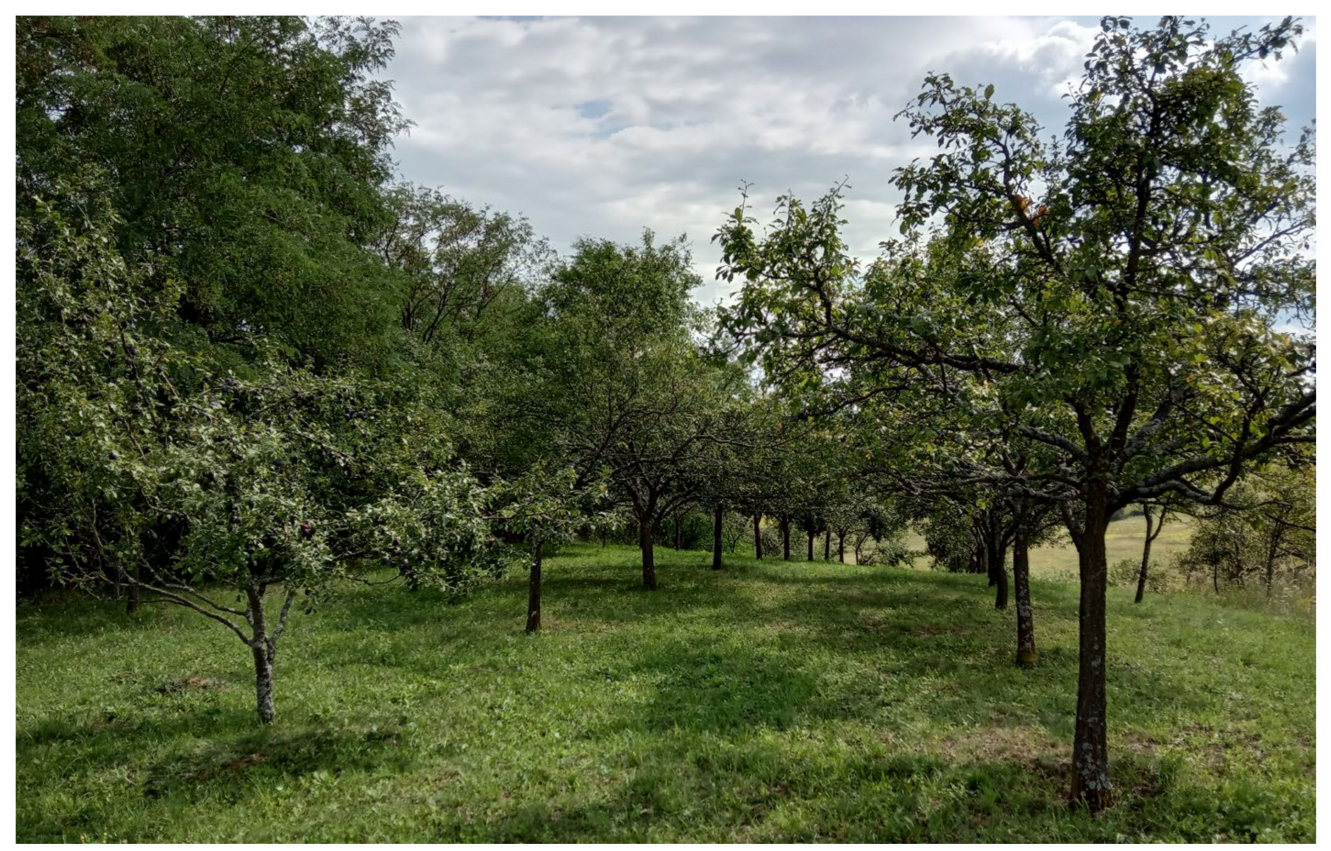

Figure 5. A typical orchard meadow where the grass is mowed, Szuhogy, NE-Hungary.

Dominant grass species differ based on the microclimate. Usually, the characteristic grass species of hay meadows (Arrhenatherum elatius, Lolium perenne, Alopecurus pratensis, Trisetum flavescens, Poa pratensis, Briza media, Anthoxanthum odoratum, Festuca pratensis, F. rubra, and Cynosurus cristatus) dominate their mesophilic and humid stands. While Brachypodium pinnatum and Bromus erectus (usually Arrhenatherum elatius, Dactylis glomerata and Helictotrichon spp. appear as well) refer to semi-dry conditions and host valuable steppe or forest-steppe species. The lawn provides a home for valuable plant species such as Dianthus collinus, D. deltoides, Anemone sylvestris, Doronicum hungaricum, Iris variegata, Clematis integrifolia, Gentianopsis ciliata, Gentiana cruciata, Listera ovata, Centaurea triumfettii, Lilium martagon, Epipactis helleborine, and Gymnadenia conopsea (Figure 6a). Abandoned stands that open up without scrub infestation host Linum tenuifolium, Chamaecytisus albus, Orchis purpurea (Figure 6b), O. tridentata (Figure 6c), O. militaris, Anacamptis morio, Neotinea ustulata, Ophrys apifera, Polygala major (Figure 6d), Aster amellus, Scabiosa canescens, Ornithogalum pyramidale, Prunella grandiflora (Figure 6e), and Pulsatilla grandis (Natura 2000 designative species). In the ecotone towards thermophilous forest fringes and white oak thickets, Prunus fruticosa, Geranium sanguineum, and Dictamnus albus enrich the habitat that is dominated by hawthorn (Crataegus monogyna) and sloe (Prunus spinosa). Even the strictly protected and Natura 2000 designative species such as Iris aphylla (Figure 6f) or Lady's slipper orchid (Cypripedium calceolus) might appear here. 


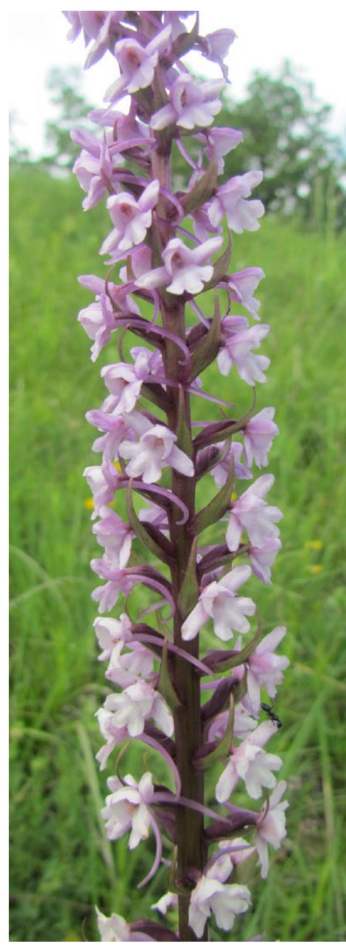

(a)

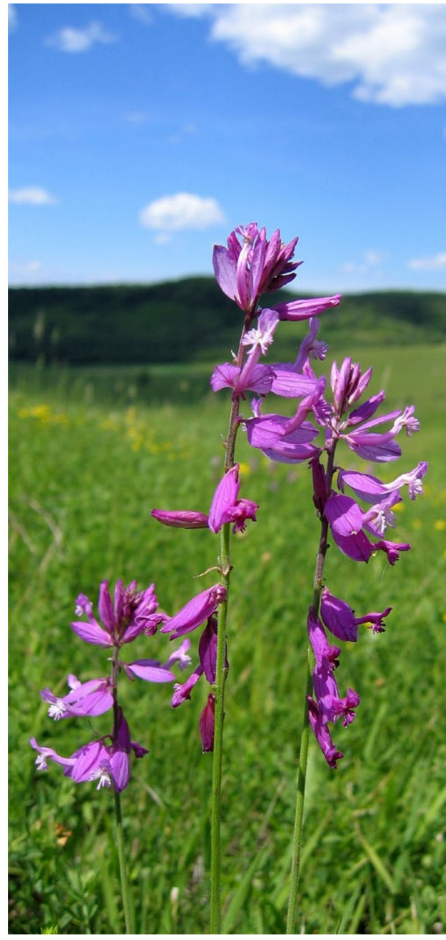

(d)

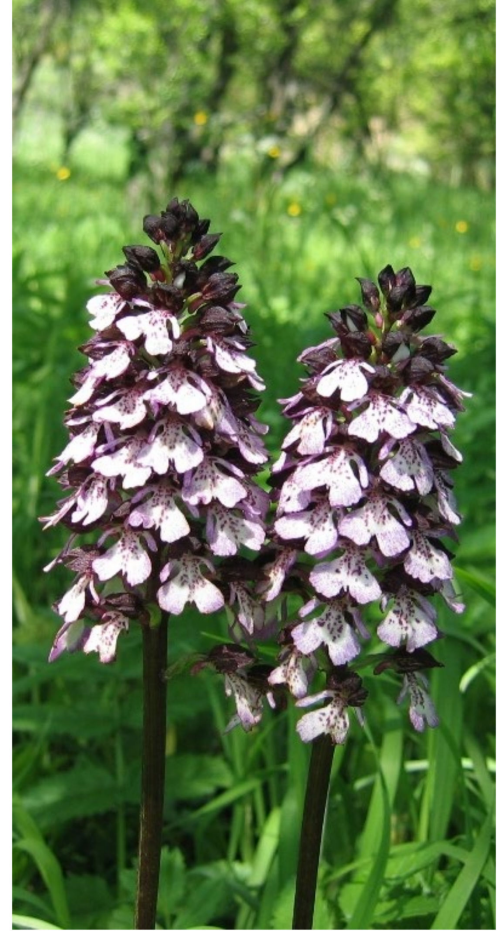

(b)

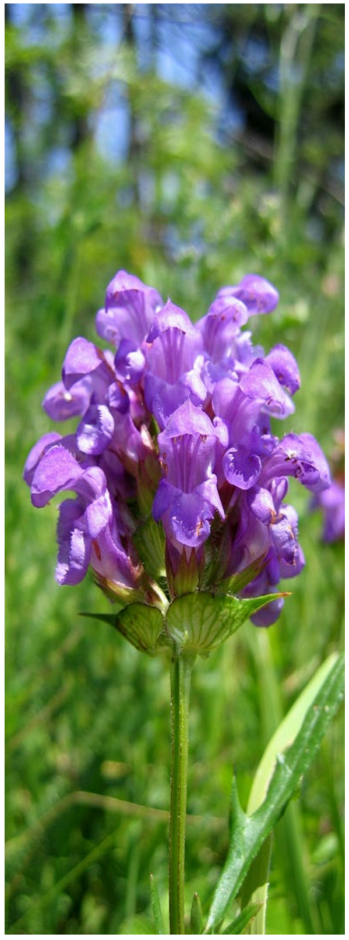

(e)

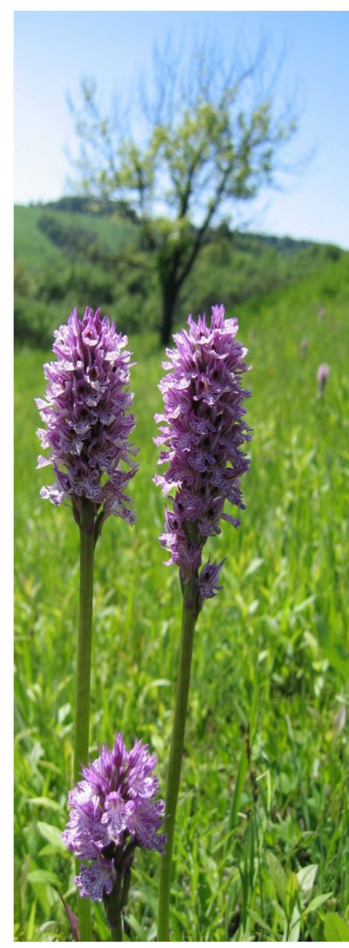

(c)

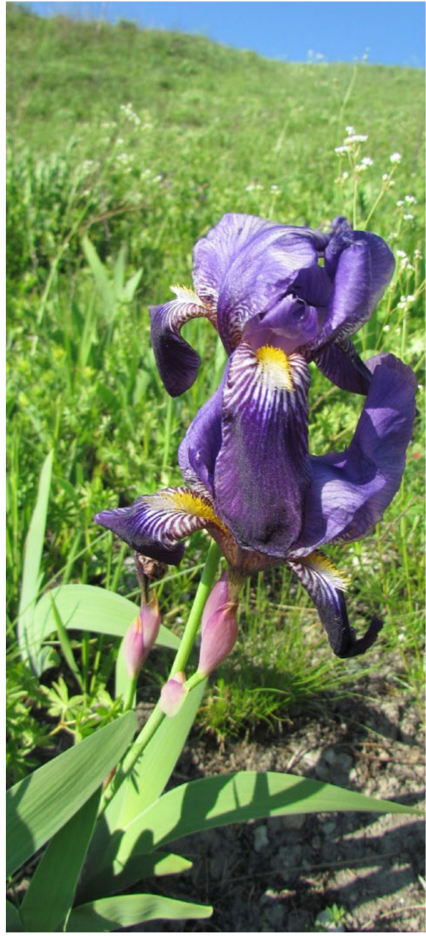

(f)

Figure 6. Protected plants in orchard grasslands: (a) The lady orchid (Orchis purpurea) among fruit trees, Serényfalva, NE-Hungary, (b) The fragrant orchid (Gymnadenia conopsea), among plum plots near Gömörszőlős, NE-Hungary (c) The Three-toothed orchid (Orchis tridentata) in an open parcel between two orchards, Kurityán, NE-Hungary, (d) The large milkwort (Polygala major) among orchards and vineyards in Zádorfalva, NE-Hungary, (e) The Bella Blue (Prunella grandiflora), (f) The steppe iris (Iris aphylla), a rare endemism appears in the ecotone between orchard meadows and oak forests, Gömörszőlős, NE-Hungary. 
Some less rare species still refer to semi-natural circumstances, such as Inula spp., Centaurea spp., Polygala comosa, Potentilla alba, Betonica officinalis, Pulmonaria mollis, Cardamine pratensis, and Jacobaea erucifolia, with Colchicum autumnale patches during autumns. At the edges adjacent to wetter and cooler habitats, tall herb fringe communities might evolve with Inula helenium or common dogwood stand (Cornus sanguinea) with the rare fern Dryopteris dilatata. More diverse exposure (southern, south-eastern, eastern, south-western, western) and slope angles (steeper or milder; tops and foothills or even valley bottoms as well) guarantee higher diversity of species and habitat types.

In the foothill regions, characterized by colluviums with deeper fertile layers, the succession of grasslands leads to scrub encroachment; however, this process is strongly set back by annual burning (Figure 7). Spring burning might be destructive for the insect fauna and plants as well, especially if done in late March or April. Succession processes affect the directions of reforestation and the generation of a mosaic-like forested steppe. Sites that are affected by regular burning (induced by local elder people who wish to sustain the view of the landscape without shrubs) have become featureless, with a much lower number of species, including those referring to disturbance (Bothriochloa ischaemum). Molinia arundinacea appearing among currently cultivated parcels (with southeastern exposition) of the upper parts of slopes refer to one-time oak forest coverage in the area (found also in historical geography works).

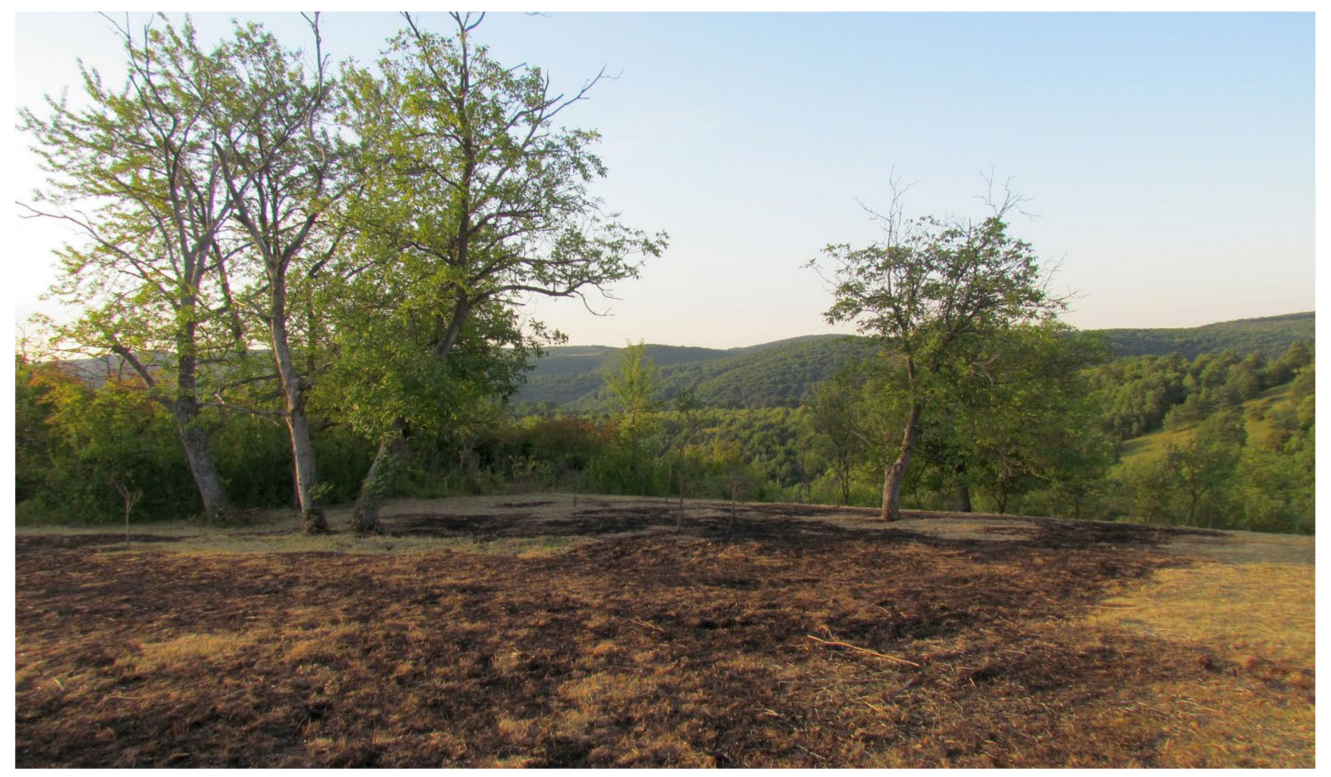

Figure 7. No claim (for hay) leads to burning the lawn and harming the trees as well, Jósvafő, NE-Hungary.

Most frequent fruit types are traditional regional or local varieties, and even some landraces, of plum, apple, peach, walnut, cherry, pear, and quince (even as a hedgerow at the edges) or sometimes sweet chestnut, medlar, or service trees.

Apricots and almonds appear in warmer regions of the country. The mosaic-like pattern of the orchard meadows as well as abandoned or still managed vineyards, pastures, unmanaged natural grasslands, small parcels of croplands (at the foothills), and thermophilous thickets or low oak forests ensure a picturesque landscape view. Hollows of the old trees host several bird species or hazel dormouse (Muscardinus avellanarius), while the flowering plants attract bees and butterflies. Hoopoes (Upupa epops) and scops owls (Otus scops) are typical in these landscapes. Ethnographical studies highly appreciate the cultural values, such as old wine cellars (used to store fruits as well), hayward huts (to protect the grape and fruit), or barns (to store the mown hay) [6,28-30]. 


\subsection{Description of Permaculture Farms with Forest Gardens - Case Studies}

There were some differences between the permaculture farms even though all of them belong to the same type of farm. Four sub-types of the five examined permaculture farms are described here.

1. Forest garden for vegetable and fruit production

There is a small-scale horticultural farm in Nagymaros, where the farmer established a forest garden on around $2000 \mathrm{~m}^{2}$ on her site (Figure 8). She produces vegetables for directly selling them to consumers, as well as fruits, mainly sea buckthorn for making a fruit juice.

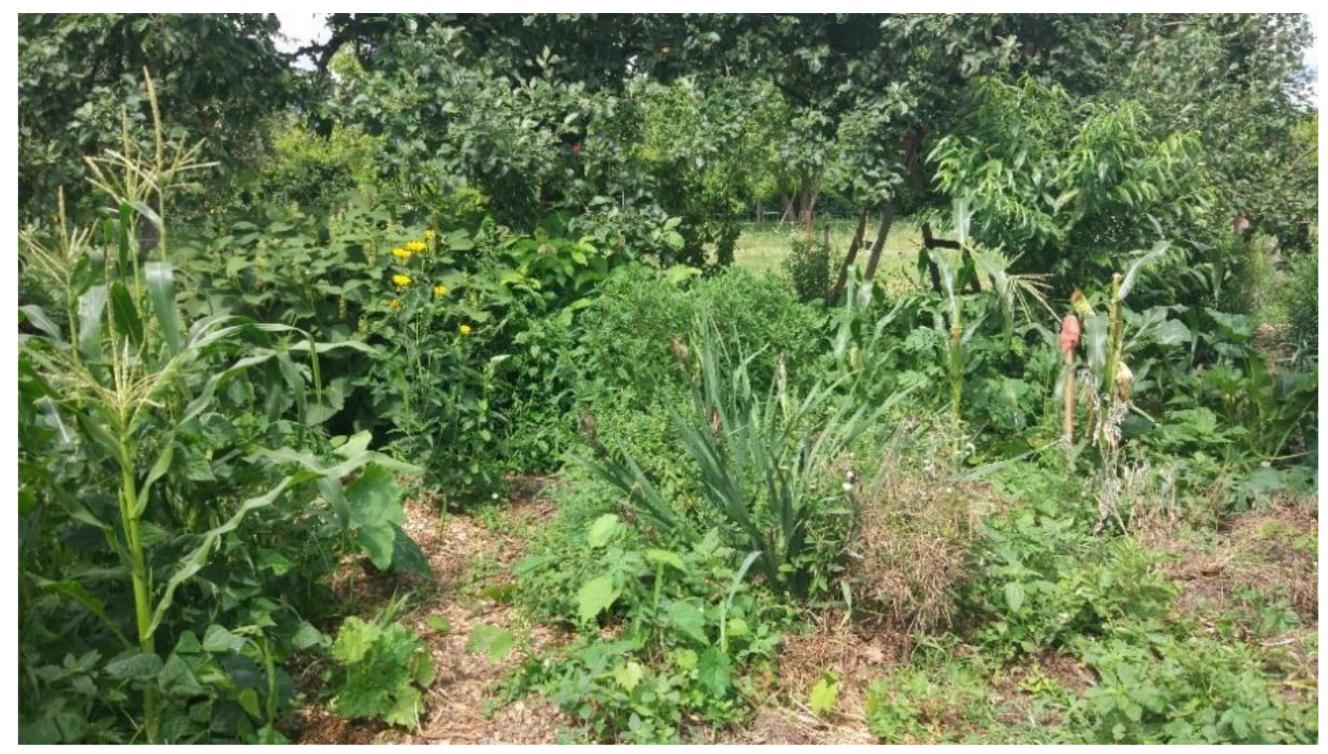

Figure 8. Forest garden with complex companion planting integrating trees, bushes and annual vegetables, and edible herbs; an example at a permaculture farm in Nagymaros, N-Hungary. The farmer used plant residues, leaves, and straw for mulching (Photo: A. Szilágyi 2020).

The garden has a more stratified layer, with diverse vegetable beds. The farmer does not apply soil cultivation, only for seed bed making, but this is very shallow, and then applies mulch with straw or other plant residues.

2. Forest garden for adaptive fruit growing

There is a larger-scale forest garden in the southwest of Hungary, in Markóc (Figure 9). It encompasses two sites, which are together around 5 hectares. Here, the farmer established a fruit forest, with taller canopy trees such as walnuts and forest tree species (oak, wild cherry, etc.) integrated with smaller fruit trees and large bushes, mainly with cornel and soft fruits. He processes a large sum of the fruits and also distills spirits with the leftover fruits. He calls his method of farming adaptive fruit growing, as he does not prune the trees except at the early stage of the trees and grafts the trees with local and traditional fruit varieties.

\section{Farm in the woods}

There is a small-scale farm near the Danube River, up in the mountains in Dunabogdány. It is a mixed farm with vegetable production, fruit orchard, and animal husbandry (Figure 10).

The farmer has chicken, pigs, and goats. He uses the pigs and goats to maintain the forestry patch on one side of his site. He collects rainwater from polytunnels and feeds a small lake that he uses for irrigation. He keeps fish in the lake, which clear the lake and also supply nutrients for the plants (Figure 11).

The farm is surrounded by forest, which creates a relatively humid microclimate. He produces soft fruits such as raspberry but also vegetables under the canopy.

4. Herbal garden with trees and shrubs 
There is a home garden where they produce herbs for processing (herbal teas and syrups) in Kóspallag, North Hungary (Figures 12 and 13).

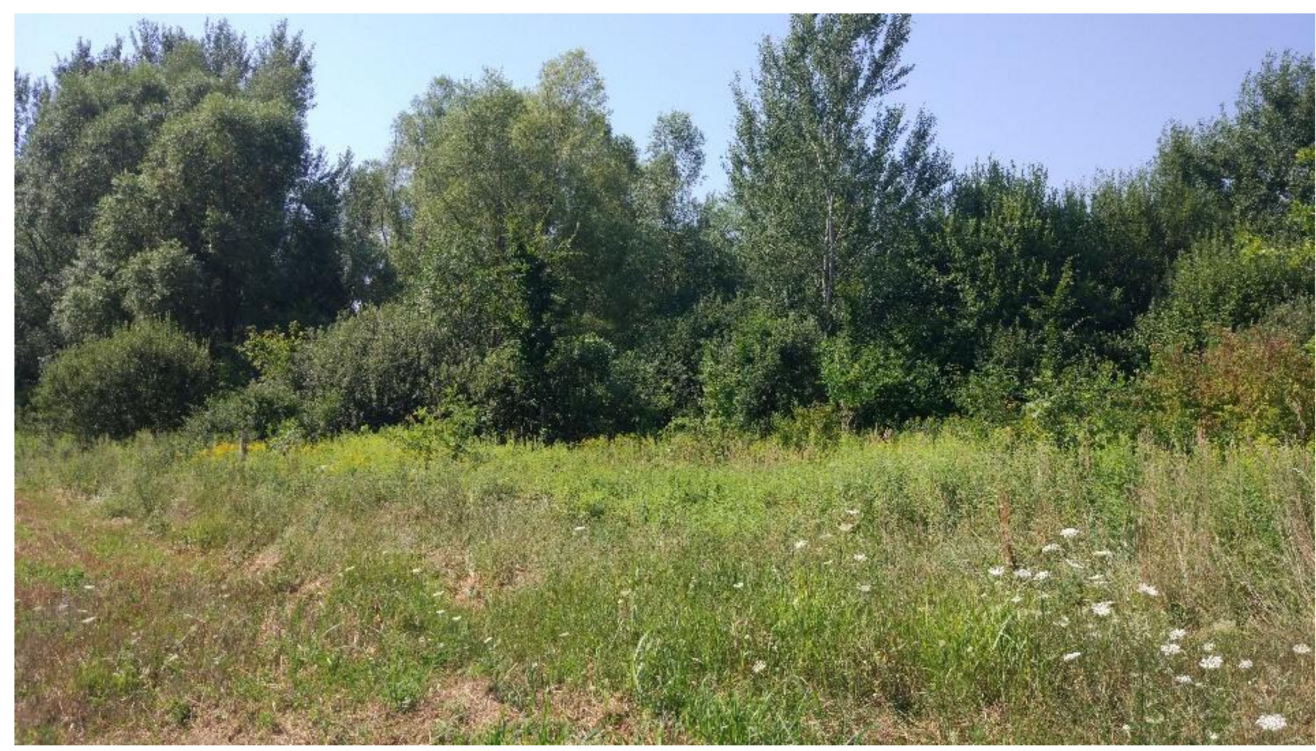

Figure 9. Adaptive fruit growing, a larger-scale forest garden example in Markóc, Hungary. The photo was taken from the neighboring conventional field edge, showing the diversity of trees at the site (Photo: A. Szilágyi 2020).

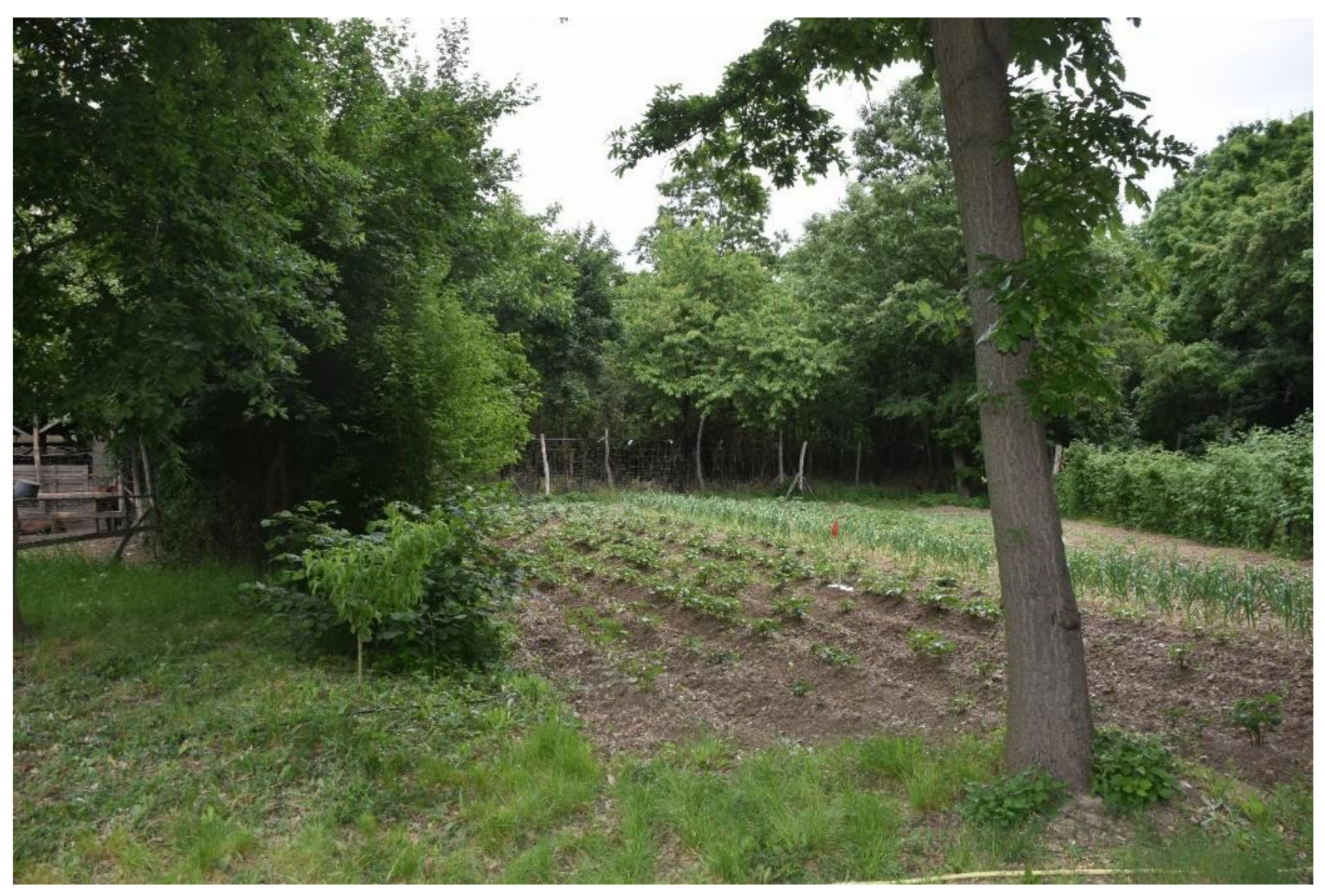

Figure 10. Vegetable field enclosed with forest and trees at a permaculture farm in Dunabogdány, $\mathrm{N}$-Hungary. In the right corner, we can see raspberry rows that can be grown only under shading in Hungary because of climate change; here, the trees provide good shade (Photo: A. Szilágyi 2020). 


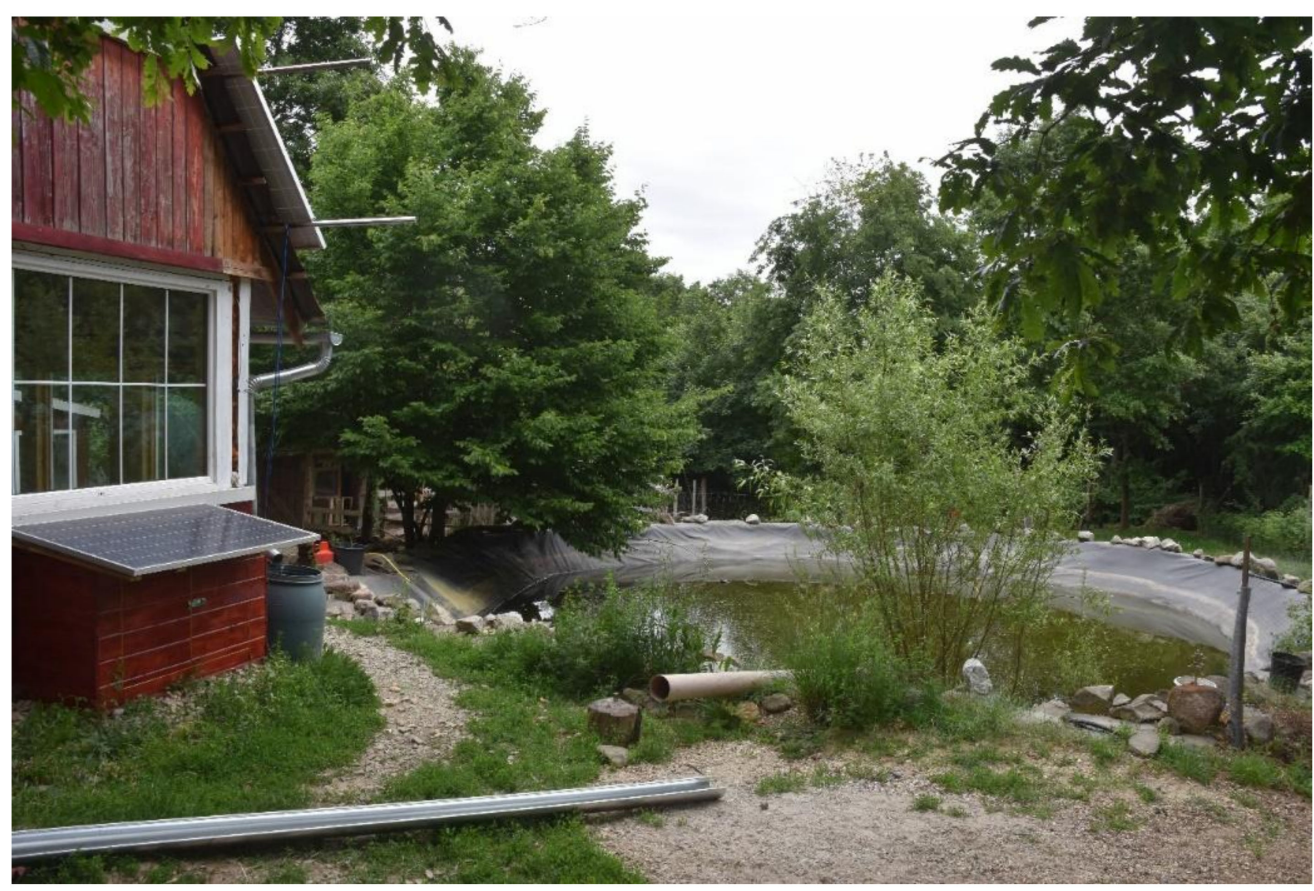

Figure 11. Water harvesting at the permaculture farm in Dunabogdány, Hungary. Rainwater from polytunnels is collected and channeled to the reservoir that is located the southern corner of the house to reflect sunshine on it. Crops are irrigated from the reservoir (Photo: A. Szilágyi 2020).

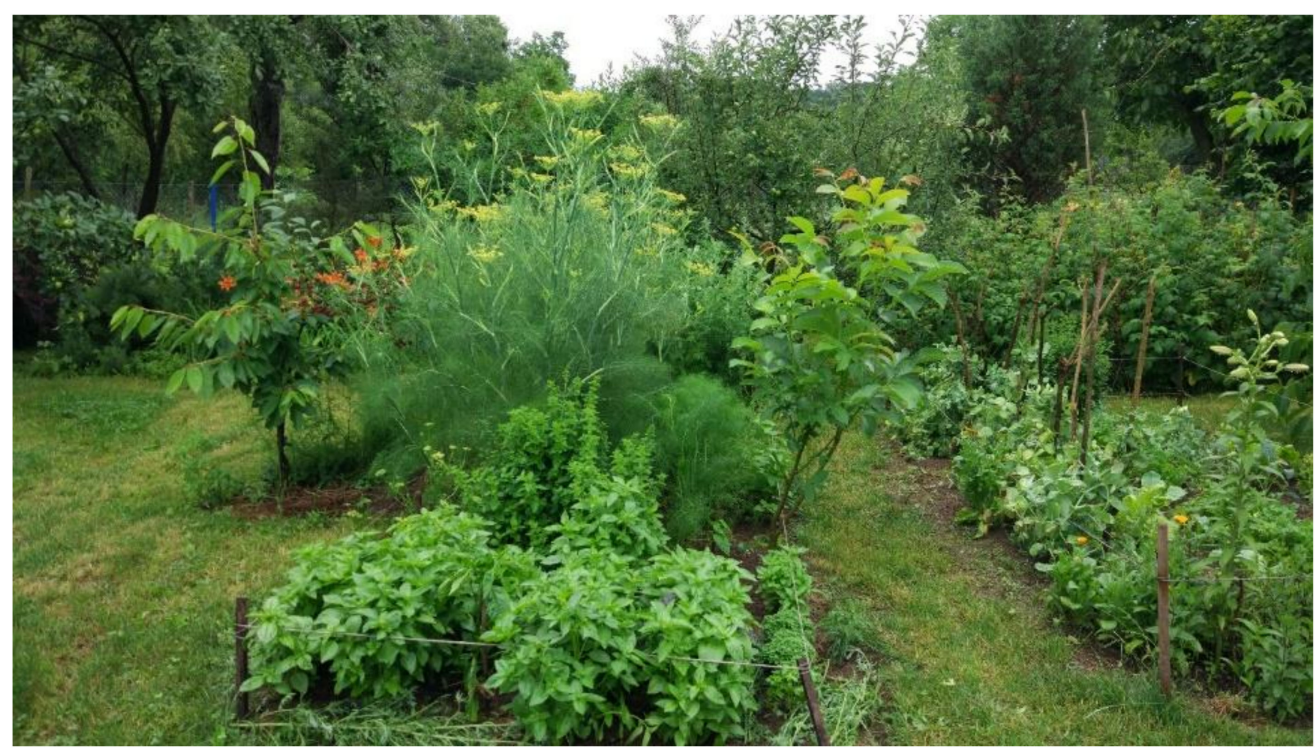

Figure 12. Polyculture beds with herbs and vegetables with surrounding fruit trees in the permaculture garden in Kóspallag, North Hungary (Photo: A. Szilágyi 2018).

The gardeners integrated herbs with vegetables and fruit trees for supplying food for the family besides the marketable herb production.

Integration of vegetables, herbs, and fruits has many advantages. Besides the efficient use of space, herbs are good companion plants for vegetables as they deter pests and attract pollinators. The farmers also collect wild herbs in the near forestry area. 


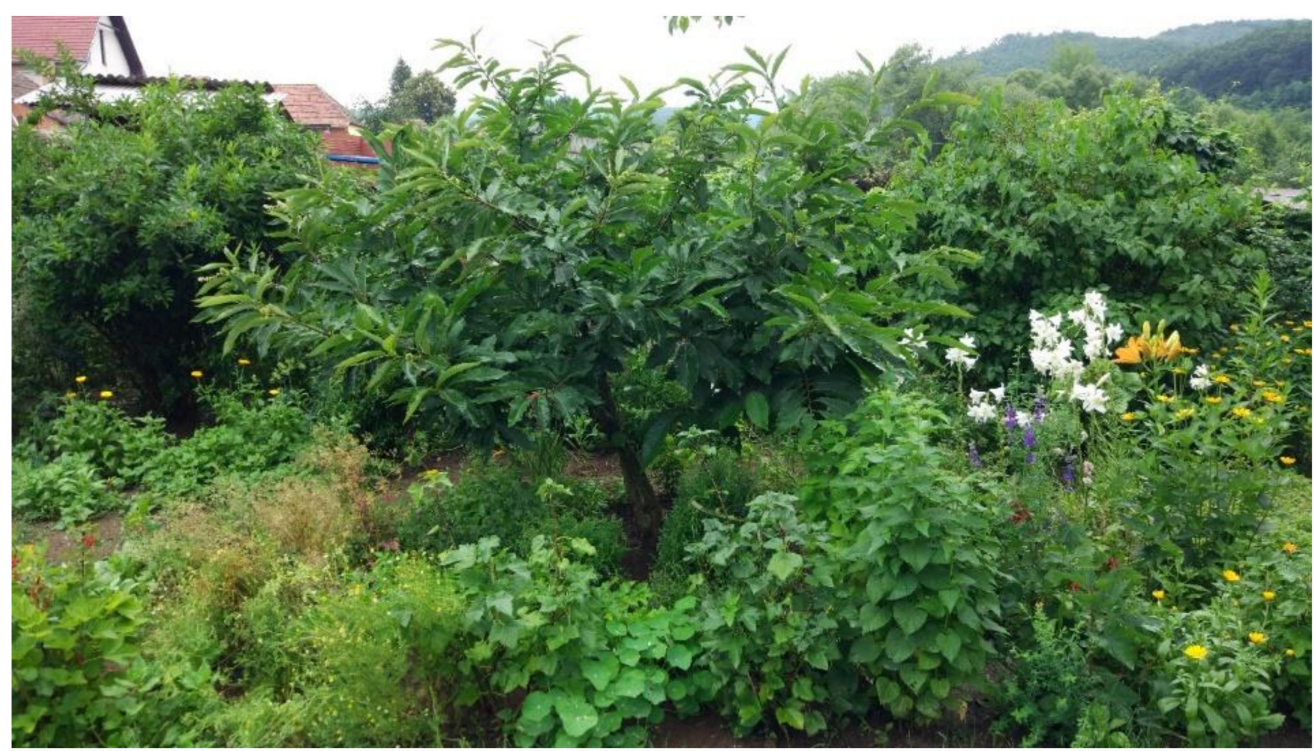

Figure 13. Perennial herbs, vegetables, and soft fruits around a sweet chestnut tree at the permaculture garden in Kóspallag, North Hungary (Photo: A. Szilágyi 2018).

\subsection{Comparative Analysis of Soil Organic Matter in Permaculture, Organic and} Conventional Farms

The highest amount of SOM (\%) was detected in the permaculture farms, reaching as high as $5.3 \%$, followed by organic farms with a maximum of $3.4 \%$, and the lowest value in the case of a conventional farm was 3.0\% (Table 2).

Table 2. Average SOM content of soils from the sampled farms.

\begin{tabular}{cccccc}
\hline Farm Code & $\begin{array}{c}\text { Average }(\mathbf{n}=\mathbf{5}) \\
\text { SOM (\%) }\end{array}$ & Farm Code & $\begin{array}{c}\text { Average }(\mathbf{n}=\mathbf{5}) \\
\text { SOM (\%) }\end{array}$ & $\begin{array}{c}\text { Farm Code } \\
\text { Average }(\mathbf{n}=5) \\
\text { SOM (\%) }\end{array}$ \\
\hline P1 & 1.6 & O1 & 3.4 & C1 & 3.0 \\
P2 & 5.2 & O2 & 3.2 & C2 & 1.6 \\
P3 & 3.1 & O3 & 3.0 & C 3 & 2.8 \\
P4 & 3.0 & O4 & 2.9 & C5 & 1.6 \\
P5 & 5.3 & O5 & 2.1 & & 1.5 \\
\hline
\end{tabular}

The analysis based on the average of the 5-5 farms did show the same tendency; the highest average SOM was in the case of the permaculture farms $(3.6 \pm 1.65 \%)$, followed by the organic farms $(2.9 \pm 0.83 \%)$, while the lowest was in the conventional farms $(2.1 \pm 0.8 \%)$ (Table 2). Regardless of the highest amount, data also show that the greatest standard deviation was also the highest in the case of permaculture farms (Table 3).

Table 3. Average and standard deviation of the SOM content in the three studied farming systems.

\begin{tabular}{ccc}
\hline Farm Types & Average SOM (\%) Values & $\begin{array}{c}\text { Standard Deviation at the } \\
\text { Farming System Level }\end{array}$ \\
\hline Permaculture $(\mathrm{n}=5)$ & 3.6 & 1.65 \\
Organic $(\mathrm{n}=5)$ & 2.9 & 0.83 \\
Conventional $(\mathrm{n}=5)$ & 2.1 & 0.80 \\
\hline
\end{tabular}

Boxplots also show the tendency very well; however, it is also visible that the mean values of permaculture and organic farms are very close, and there is an overlap in the data between the permaculture and organic, and between the organic and conventional farms, while permaculture and conventional farms are quite nicely separated with very little overlap between them (Figure 14). 


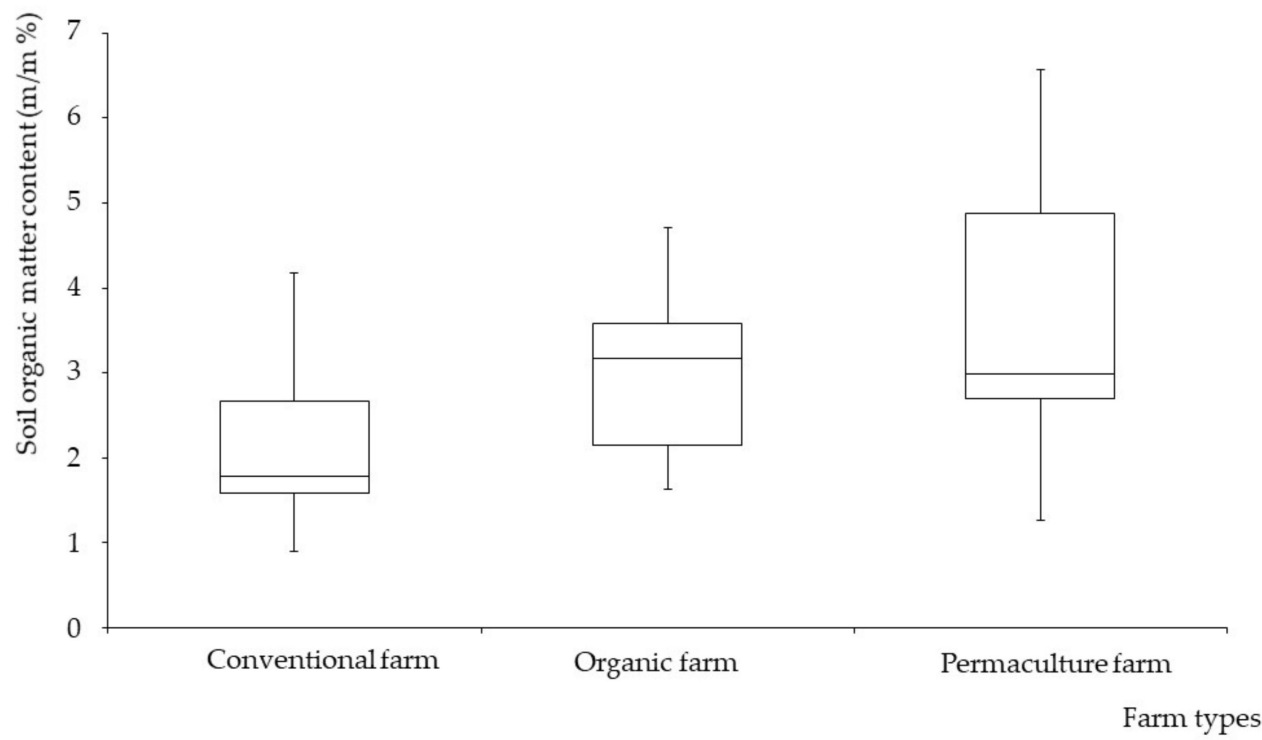

Figure 14. Soil Organic Matter content of the three studied farming systems.

All data show the tendency of the following order of the SOM content: conventional farms $<$ organic farms $<$ permaculture farms.

The Shapiro-Wilk test proved that the data shows normal distribution in all groups (conventional, organic, and permaculture farms), so ANOVA can be used. ANOVA showed strong significant differences between the groups $(\mathrm{n}=25-25-25, \mathrm{~F} 2,72=10,621, p<0.001)$.

\section{Discussion}

The distribution of the wood-pastures and their density map was introduced in the Northern Medium Hungarian Mountain Ranges, based on the topography maps prepared around the 1980s. This map proved that there were numerous wood-pastures in this region by the time of the topographic map surveys. The reason for the high number of appearances of these wood-pastures on the topographic maps in the 1980s (it is important because they started to disappear before the 1980s) is that they played a determining role in the landscape and agriculture for centuries [46,47]. On the other hand, some of them are under the protection of nature conservation, and some national park rangers are responsible (officially designated) for their management or just feel responsible and conduct the management due to internal motivation. However, due to their decline, which started in the 1950s, these are the 6th most endangered semi-natural, wooded natural areas in Hungary [26]. Based on the survey of Varga et al. [48], there are still $\sim 33,000$ ha wood-pastures in Hungary, and $28 \%$ are under some kind of local or national protection. Further, $60 \%$ belongs to the Natura 2000 network (which can also be considered as national but Natura 2000 designations are due to EU accessions). There is still a lot to do as only $20 \%$ of the wooded grasslands are under the scope of research activities [49].

There are 10 protected wood-pastures all over the country with local interest (Dénesfa, Kerkafalva, Péterhida, Nagyrécse, Keszü, Márianosztra, Nagybajom, Olaszfalu, Patapoklosi, Hatvan-Kisgombos), and three are of national importance and are in the category 'nature conservation area' (Csokonyavisonta, Erdőbénye, Márkházapuszta). Some woodpastures belong to larger protected natural areas, such as national parks and landscape protection areas, e.g., Bélmegyer, Túristvándi, Cserépfalu, Hollókő.

Due to the European Union's Biodiversity Strategy for 2030, "the improving the condition and diversity of agroecosystems will increase the sector's resilience to climate change, environmental risks and socioeconomic shocks, while creating new jobs, for example in organic farming, rural tourism or recreation" (http:/ / www.fao.org/agroecology/database/ detail/en/c/1276986/ (accessed on 31 May 2021)). These ambitious aims can be achieved partly through the use of these forms of agricultural production, with a combination of 
food production and nature conservation that we see in the case of the wood-pastures that ensures the maintenance of good environmental conditions while providing healthy and local agricultural products, admirable landscapes for tourism, refuges for pollinators, etc. A similar form of agricultural production is the orchard grasslands. The presented natural values related to orchard grasslands (meadows, pastures, and mixed-use) also proved that food production is possible with the protection of natural values (and almost zero pressure on the environment). Their importance is highlighted in many other types of research in Europe $[32,36,50]$.

The recent example "mainly" shows the botanical values but there are zoological ones of course. The recent interest is related to pollinators as this is dealt with in many studies. Steffan-Dewenter and Leschke [51] investigated the effects of habitat management on vegetation and above-ground nesting bees and wasps in orchard meadows in Central Europe. They called attention to the importance of man-made, semi-natural areas in relation to nature conservation, along with Tscharntke et al. 2002 [52].

The reason for the deterioration of traditional, non-intensive agricultural farming for decades was due to their adverse economic effects [53]. There were several attempts to change the simply economic approach of evaluation of agricultural production, including the impressive approach defined by Camagni [54], who stated that space is not just a geographical container, it is an economic resource in itself, and, besides other assets, its externalities reinforce innovation processes at the local level. The introduction of the concept of territorial, natural, and ecological capital in regional development helps the understanding of the importance and relevance of traditional, non-intensive farm management forms tremendously.

The other concept along this line is the concept of ecosystem services [55-57]. The ecosystem service concept evaluates the added value of agricultural production, thus not only the production value is included in the evaluation that helps the understanding of the value of the traditional agricultural landscapes and their management.

Based on our present knowledge on permaculture farms, these farms might provide a solution for producing a wider range of products than wood-pastures and orchard grasslands while maintaining good environmental conditions and the possibility for biodiversity conservation. In the present article, "only" the soil organic matter was examined and proved that the highest amount of organic matter was found in the soils of permaculture farms. There are more indicators that can prove that permaculture can be a future solution for producing high amounts and healthy agricultural products with little stress on nature and environment. There is a large potential in increasing these areas as the already cited "European Union's Biodiversity Strategy for 2030" requires the increase of agricultural areas with organic farming to $25 \%$.

The examined permaculture farms included trees and/or partially forested areas on the farms, which makes this kind of farming or management similar to that of woodpastures and orchard grasslands where food production and wood are included in the management system. This can be an optimal future solution for farming activities, as trees play a crucial role in climate and also in micro-climate regulations, provide shade for plants and animals, can prevent soil moisture (not all species of course) and wind and water erosion, can improve the quality of soil life, and furthermore, as an important ecosystem service, provide wood for fuelwood and construction materials.

\section{Conclusions}

The literature review and map analyses proved that wood-pastures had an important role in Hungarian agricultural production. The high number of wood-pastures that are still recognizable on maps gives hope for future use of these ancient land management forms.

The botanical surveys suggest that managing agricultural land as fruit grasslands is suitable for protecting natural values, besides fruit production.

The very meaning/definition of permaculture is already a way forward in our agricultural production. This form (or these forms as we have already seen several types or 
sub-types) of farming can provide a better chance for sustainable land use, especially for preserving SOM.

Based on the presented cases for alternative, non-intensive, non-invasive agricultural management forms, we can conclude that there are good opportunities for various farming activities, where win-win situations can be achieved: food production is possible with the conservation of natural values and less stress on the environment (less chemical use, wind erosion, water erosion, higher organic matter content, richer soil biodiversity, etc.).

Author Contributions: C.C. conceptualized and C.C., Á.M., A.S., D.S. and O.G. wrote the manuscript with inputs of co-authors; Z.B. did the formal analysis, D.S., C.C., A.S. and J.S. produced maps; all authors helped with final review and supervision. All authors have read and agreed to the published version of the manuscript.

Funding: This research received no external funding.

Institutional Review Board Statement: Not applicable.

Informed Consent Statement: Not applicable.

Data Availability Statement: Not applicable.

Conflicts of Interest: The authors declare no conflict of interest.

\section{References}

1. Fróna, D.; Szenderák, J.; Harangi-Rákos, M. The Challenge of Feeding the World. Sustainability 2019, 11, 5816. [CrossRef]

2. Mehrabi, Z.; Ellis, E.C.; Ramankutty, N. The challenge of feeding the world while conserving half the planet. Nat. Sustain. 2018, 1, 409-412. [CrossRef]

3. Dover, M.; Talbot, L. To Feed the Earth Agro-Ecology for Sustainability in a Changing World Order; World Resources Institute: Washington, DC, USA, 1987; p. 122.

4. Pimentel, D.; McLaughlin, L.; Zepp, A.; Lakitan, B.; Kraus, T.; Kleinman, P.; Vancini, F.; Roach, W.; Graap, E.; Keeton, W.S.; et al. Environmental and economic effects of reducing pesticide use in agriculture. Agric. Ecosyst. Environ. 1993, 46, 273-288. [CrossRef]

5. Santoro, A.; Venturi, M.; Ben Maachia, S.; Benyahia, F.; Corrieri, F.; Piras, F.; Agnoletti, M. Agroforestry Heritage Systems as Agrobiodiversity Hotspots. The Case of the Mountain Oases of Tunisia. Sustainability 2020, 12, 4054. [CrossRef]

6. Centeri, C.; Renes, H.; Roth, M.; Kruse, A.; Eiter, S.; Kapfer, J.; Santoro, A.; Agnoletti, M.; Emanueli, F.; Sigura, M.; et al. Wooded Grasslands as Part of the European Agricultural Heritage. In Environmental History in the Making; Springer: Berlin/Heidelberg, Germany, 2016; Volume 5, pp. 75-103.

7. Gillet, F. Modelling vegetation dynamics in heterogeneous pasture-woodland landscapes. Ecol. Model. 2008, 217, 1-18. [CrossRef]

8. Garbarino, M.; Lingua, E.; Subirà, M.M.; Motta, R. The larch wood pasture: Structure and dynamics of a cultural landscape. Eur. J. For. Res. 2010, 130, 491-502. [CrossRef]

9. Nel, L.; Szilágyi, A. Selection of indicators for assessment of soil-related agricultural ecosystem services and sustainable management. In 25th International Poster Day and Institute of Hydrology Open day: Transport of Water, Chemicals and Energy in the Soil-Plant-Atmosphere System; Anežka, Č., Ed.; Institute of Hydrology SAS: Bratislava, Slovakia, 2018; pp. 103-118. ISBN 9788089139422.

10. Lesschen, J.P.; Elbersen, B.; Hazeu, G.; van Doorn, A.; Mucher, S.; Velthof, G. Task 1—Defining and Classifying Grasslands in Europe. In Final Report March 2014; Alterra, part of Wageningen UR: Wageningen, The Netherlands, 2014.

11. Joffre, R.; Vacher, J.; de Llanos, C.; Long, G. The dehesa: An agrosilvopastoral system of the Mediterranean region with special reference to the Sierra Morena area of Spain. Agrofor. Syst. 1988, 6, 71-96. [CrossRef]

12. Rackham, O. Trees and Woodland in the British Landscape-The Complete History of Britain's Trees, Woods és Hedgerows; Phoenix Giant: London, UK, 1996; p. 234.

13. Manning, A.; Fischer, J.; Lindenmayer, D.B. Scattered trees are keystone structures-Implications for conservation. Biol. Conserv. 2006, 132, 311-321. [CrossRef]

14. Rois-Díaz, M.; Mosquera-Losada, R.; Rigueiro-Rodríguez, A. Biodiversity Indicators on Silvopastoalism across Europe. EFI Technical Report 21; European Forest Institute: Joensuu, Finland, 1999; p. 66.

15. Vera, F.W.M. Grazing Ecology and Forest History; CABI: Wallingford, UK, 2000; p. 506.

16. Schnabel, S.; Ferreira, A. Sustainability of Agrosilvopastoral Systems-Dehesas, Montados; Advances in Geoecology: Reiskirchen, Germany, 2004; Volume 37.

17. Eichhorn, M.P.; Paris, P.; Herzog, F.; Incoll, L.D.; Liagre, F.; Mantzanas, K.; Mayus, M.; Moreno, G.; Papanastasis, V.P.; Pilbeam, D.J.; et al. Silvoarable Systems in Europe-Past, Present and Future Prospects. Agrofor. Syst. 2006, 67, 29-50. [CrossRef]

18. Holl, K.; Smith, M. Scottish upland forests: History lessons for the future. For. Ecol. Manag. 2007, 249, 45-53. [CrossRef]

19. Bergmeier, E.; Petermann, J.; Schröder, E. Geobotanical survey of wood-pasture habitats in Europe: Diversity, threats and conservation. Biodivers. Conserv. 2010, 19, 2995-3014. [CrossRef] 
20. Tiessen, H.; Menezes, R.; Salcedo, I.; Wick, B. Organic matter transformations and soil fertility in a treed pasture in semiarid NE Brazil. Plant Soil 2003, 252, 195-205. [CrossRef]

21. Ellis, E.A.; Nair, P.; Jeswani, S.D. Development of a web-based application for agroforestry planning and tree selection. Comput. Electron. Agric. 2005, 49, 129-141. [CrossRef]

22. Keesman, K.J.; Graves, A.; Van Der Werf, W.; Burgess, P.J.; Palma, J.; Dupraz, C.; Van Keulen, H. A system identification approach for developing and parameterising an agroforestry system model under constrained availability of data. Environ. Model. Softw. 2011, 26, 1540-1553. [CrossRef]

23. Nair, P.K.R.; Garrity, D. Agroforestry research and development-The way forward. In Agroforestry-The Future of Global Land Use; Nair, P.K.R., Garrity, D., Eds.; Springer: Dordrecht, Germany, 2012; p. 541.

24. Jose, S. Agroforestry for conserving and enhancing biodiversity. Agrofor. Syst. 2012, 85, 1-8. [CrossRef]

25. Jørgensen, D.; Quelch, P. The origins and history of medieval wood-pastures. In European Wood-Pastures in Transition: A SocialEcological Approach; Hartel, T., Plieninger, T., Eds.; Taylor \& Francis Group: New York, NY, USA, 2014; pp. 55-69.

26. Molnár, Z.; Bölöni, J.; Horváth, F. Threatening factors encountered: Actual endangerment of the Hungarian (semi-) natural habitats. Acta Bot. Hung. 2008, 50, 199-217. [CrossRef]

27. Bölöni, J.; Molnár, Z.; Bíró, M.; Horváth, F. Distribution of the (semi-) natural habitats in Hungary II. Woodlands and shrublands. Acta Bot. Hung. 2008, 50, 107-148. [CrossRef]

28. Petercsák, T. The role of forest in the mountain animal husbandry. In A Herman Ottó Múzeum Évkönyve 16; Bodó, S., Szabadfalvi, J., Eds.; Annales Musei Miskolciensis De Herman Otto Nominati: Miskok, Hunguary, 1977; pp. 295-309. (In Hungarian)

29. Petercsák, T. The forest in the peasant farming if the Northern Medium Mountain Range (18th to 20th century). Studia Folklor. Ethnogr. 1992, 30, 239. (In Hungarian)

30. Mravcsik, Z.; Harmos, K.; Malatinszky, Á. Studies on botany and landscape history of abandoned grapeyards in the Northern Cserhát Hills, Hungary. Tájökológiai Lapok 2009, 7, 473-484.

31. Dobrovodská, M.; Kanka, R.; David, S.; Kollár, J.; Špulerová, J.; Štefunková, D.; Mojses, M.; Petrovič, F.; Kristin, A.; Stašiov, S.; et al. Assessment of the biocultural value of traditional agricultural landscape on a plot-by-plot level: Case studies from Slovakia. Biodivers. Conserv. 2019, 28, 2615-2645. [CrossRef]

32. Forejt, M.; Syrbe, R.-U. The current status of orchard meadows in Central Europe: Multi-source area estimation in Saxony (Germany) and the Czech Republic. Morav. Geogr. Rep. 2019, 27, 217-228. [CrossRef]

33. Malatinszky, Á.; Siller, I.; Penksza, K. Abandoned loessy grape yards as refuges of rare steppe plant species. Cereal Res. Commun. 2008, 36, 1139-1142.

34. Herzog, F. Streuobst: A traditional agroforestry system as a model for agroforestry development in temperate Europe. Agrofor. Syst. 1998, 42, 61-80. [CrossRef]

35. Bouvier, J.-C.; Boivin, T.; Lavigne, C. Conservation value of pome fruit orchards for overwintering birds in southeastern France. Biodivers. Conserv. 2020, 29, 3169-3189. [CrossRef]

36. Zarnovican, H.; Kollár, J.; Škodová, I. Grassland communities of traditional orchards in the Western Carpathians (Slovakia). Acta Soc. Bot. Pol. 2017, 86, 3552. [CrossRef]

37. Kun, R.; Bartha, S.; Malatinszky, Á.; Molnár, Z.; Lengyel, A.; Babai, D. "Everyone does it a bit differently!”: Evidence for a positive relationship between micro-scale land-use diversity and plant diversity in hay meadows. Agric. Ecosyst. Environ. 2019, 283, 106556. [CrossRef]

38. Mollison, B. Permaculture, A Designer's Manual; Tagari Publications: Sisters Creek, Australia, 1988; p. 565.

39. Holmgren, D.; Mollison, B. Permaculture One: A Perennial Agriculture for Human Settlements; Tagari Publications: Sisters Creek, Australia, 1990; p. 127.

40. Holmgren, D. Permaculture, Principles E Pathways Beyond Sustainability; Permanent Publications: Hampshire, UK, $2002 ;$ p. 286.

41. Baji, B. Permakultúra és Önellátó Biogazdálkodás, 3rd ed.; Első Lánchíd Bt.: Biri, Hunguary, 2013; p. 224.

42. Jacke, D.; Toensmeier, E. Edible forest gardens. In Ecological Vision and Theory for Temperate Climate Permaculture; Chelsea Green Publishing: Chelsea, VT, USA, 2005; Volume 1, p. 396.

43. Ferguson, R.S.; Lovell, S. Permaculture for agroecology: Design, movement, practice, and worldview. A review. Agron. Sustain. Dev. 2014, 34, 251-274. [CrossRef]

44. Crawford, M. Creating a Forest Garden: Working with Nature to Grow Edible Crops; Chelsea Green Publishing: Chelsea, VT, USA, 2010; p. 384.

45. Saláta, D. Az Északi-Középhegység fás Legelőinek Tipológiája és Természetvédelmi Vonatkozásai (Tipology and Nature Conservational Aspects of Wood Pastures in the North Hungarian Mountains, English Thesis); Szent István Egyetem, Környezettudományi Doktori Iskola: Gödöllő, Hunguary, 2017; p. 131. Available online: http://phd.szie.hu/?docId=15658 (accessed on 31 May 2021).

46. Bartha, D. Történelmi erdőhasználatok Magyarországon. Magy. Tudomány 2003, 12, 90-102.

47. Szabó, P. Woodland and Forests in Medieval Hungary. In Woodland and Forests in Medieval Hungary; BAR Publishing: Oxford, UK, 2005; p. 187. 
48. Varga, A.; Bölöni, J.; Saláta, D.; Biró, M.; Horváth, F.; Samu, Z.T.; Bodor, Á.; Molnár, Z. Magyarországi Fáslegelők és Legelőerdők Jelenlegi Természetvédelmi Helyzete és Problémái (Present state and Problems of Nature Conservation of Hungarian Woodpastures and Pasture Forests). In Aktuális Flóra-És Vegetációkutatás a Kárpát-medencében Nemzetközi Konferencia Absztraktkötete (Actual Flora and Vegetation Research of the Carpathian Basin); Schmidt, D., Kovács, M., Bartha, D., Eds.; Nyugat-magyarországi Egyetemi Kiadó: Sopron, Hunguary, 2014; p. 225.

49. Varga, A.; Molnár, Â.; Tölgyesi, C.; Gallé, R.; Molnár, Z. Az Erdei Legeltetés Hatásainak Vizsgálata a Duna-Tisza-Közén; BudapestVácrátót, Kiskunság National Park Directorate-Hungarian Academy of Science Centre for Ecological Research: Budapest, Hungary, 2015; p. 107.

50. Plieninger, T.; Levers, C.; Mantel, M.; Costa, A.; Schaich, H.; Kuemmerle, T. Patterns and Drivers of Scattered Tree Loss in Agricultural Landscapes: Orchard Meadows in Germany (1968-2009). PLoS ONE 2015, 10, e0126178. [CrossRef]

51. Steffan-Dewenter, I.; Leschke, K. Effects of habitat management on vegetation and above-ground nesting bees and wasps of orchard meadows in Central Europe. Biodivers. Conserv. 2003, 12, 1953-1968. [CrossRef]

52. Tscharntke, T.; Steffan-Dewenter, I.; Kruess, A.; Thies, C. Contribution of small habitat fragments to conservation of insect communities of grassland-cropland landscapes. Ecol. Appl. 2002, 12, 354-363.

53. Schönhart, M.; Schauppenlehner, T.; Schmid, E.; Muhar, A. Analysing the maintenance and establishment of orchard meadows at farm and landscape levels applying a spatially explicit integrated modelling approach. J. Environ. Plan. Manag. 2011, 54, 115-143. [CrossRef]

54. Camagni, R. Regional Competitiveness: Towards a Concept of Territorial Capital. In Modelling Regional Scenarios for the Enlarged Europe; Capello, R., Camagni, R., Fratesi, U., Chizzolini, B., Eds.; Springer: Berlin/Heidelberg, Germany, 2008 ; pp. $33-48$.

55. Daily, G.C. Nature's Services: Societal Dependence on Natural Ecosystems; Island Press: Washington, DC, USA, 1997.

56. Kovács, E.; Kelemen, E.; Kalóczkai, Á.; Margóczi, K.; Pataki, G.; Gébert, J.; Málovics, G.; Balázs, B.; Roboz, Á.; Krasznai Kovács, E.; et al. Understanding the links between ecosystem service trade-offs and conflicts in protected areas. Ecosyst. Serv. 2015, 12, 117-127. [CrossRef]

57. Prohászka, V.; Kollányi, L.; Máté, L.; Zaja, P.; Lantos, T.; Kovács, E. Assessment of ecosystem services in adaptive orchard meadows in Visnyeszéplak. In Sustainability in Transforming Societies, Proceedings of the 26th Annual Conference of the International Sustainable Development Research Society Budapest, Hungary, 15-17 July 2020; Zilahy, G., Ed.; Faculty of Economic and Social Sciences, Budapest University of Technology and Economics: Budapest, Hungary, 2020; pp. 948-956. 